\title{
Assessment of sperm production and reproductive organs of Wistar rats to long-term exposure of Caesalpinia ferrea
}

\author{
LEDA M.F. LUCINDA ${ }^{1}$, CAMILA B. ROCHA ${ }^{1}$, MAYCON M. REBOREDO ${ }^{1}$, \\ VINÍCIUS C. FARIA ${ }^{1}$ and RITA C.S. SÁ ${ }^{2}$ \\ ${ }^{1}$ Universidade Federal de Juiz de Fora, Centro de Biologia da Reprodução, Rua José Lourenço Kelmer, s/n \\ Campus Universitário, Bairro São Pedro, 36036-900 Juiz de Fora, MG, Brasil \\ ${ }^{2}$ Universidade Federal da Paraíba, Departamento de Fisiologia e Patologia \\ Cidade Universitária, 58059-900 João Pessoa, PB, Brasil
}

Manuscript received on February 5, 2009; accepted for publication on June 24, 2010

\begin{abstract}
Caesalpinia ferrea Mart (Leguminosae) is a medicinal plant used to treat diabetes, among other therapeutic properties, but which is also reported to have hepatotoxic effects. Although it contains substances such as flavonoids and coumarin, which are known to have antifertility activity, no studies have apparently been conducted to evaluate the potential adverse side effects of this plant on the function of the reproductive system after a chronic treatment. Therefore, this investigation was carried out to evaluate the effect and safety of the long-term exposure to C. ferrea on male Wistar rats' vital organs, reproductive system and sperm production. Adult and immature male rats were treated with an aqueous extract of $C$. ferrea at a dose level of $300 \mathrm{mg} / \mathrm{kg}$ of body weight, administered during one or two spermatogenic cycles of this species. The reproductive and vital organs were analyzed, and sperm was collected from the epididymal secretion of the right epididymis cauda. The long-term administration of $C$. ferrea did not significantly alter the body, vital and reproductive organs weights. Gamete production was not affected either. The chronic assessment of $C$. ferrea suggests that this plant does not affect the normal functioning of the Wistar rat reproductive system.
\end{abstract}

Key words: Caesalpinia ferrea, Wistar rat, reproductive system, toxicological assessment, chronic and sub-chronic treatment.

\section{INTRODUCTION}

Caesalpinia ferrea Mart (Leguminosae), popularly known in Brazil as "Pau-ferro" or "Juca", is a plant commonly used by the population for its antiulcerogenic (Bachi et al. 1995), anti-inflammatory (Carvalho et al. 1996) and cancer chemopreventive properties (Nakamura et al. 2002). This plant is also used for treating respiratory tract diseases, dysentery, diabetes (Bragança 1996) and liver inflammation (Di Stasi et al. 2002), although the occurrence of hepatotoxicity has been reported in the literature (Di Stasi et al. 2002). Phytochemical studies have shown the presence of sitosterol,

Correspondence to: Rita de Cássia S. Sá

E-mail: ritacassia.sa@bol.com.br flavonoids, saponins, tanins, coumarins, steroids and phenolic compounds in the hydroalcoholic extract of the stem bark and leaves of $C$. ferrea (Gonzalez et al. 2004). Flavonoids have been shown to produce antiandrogenic activity and affect male fertility in dogs (Bhargava 1989) whereas coumarin, a well-known liver toxicant (Born et al. 2000), has been reported to have antifertility activity in mature female rats (Ulubelen et al. 1994). Sitosterol, a weak estrogenic phytosterol used for lowering cholesterol and treating benign prostatic hyperplasia (Kritchevsky and Chen 2005), was reported to have caused decreased sex steroid concentrations in fish (MacLatchy and Van Der Kraak 1995) and lowered sperm counts in rats (Malini and Vanithakumari 1991). 
In addition, the administration of an aqueous extract of $C$. ferrea to Wistar rats submitted to a short-term bioassay showed a non-significant weight reduction of the seminal vesicle (Reboredo et al. 2006).

Reproductive toxicity is linked to the occurrence of adverse effects expressed as alterations to the reproductive organs, the related endocrine and nervous systems, or pregnancy outcomes. Toxicity for males may result from adverse effects on sexual maturation, gamete production and transport, sexual behavior and fertility (Kimmel et al. 1995). A variety of chemical and physical agents, including the natural occurring substances found in plants, have been associated with male reproductive toxicity (Dixit et al. 1989, Montanari et al. 1998, He et al. 2010, Wang et al. 2010). Folk medicine is traditionally employed by many people throughout the world. However, the clinical knowledge on the effectiveness of plants in the treatment of diseases and fertility-related problems, as well as the risks and nature of any adverse side effects, are quite often not clearly determined.

Acute, chronic and subchronic tests are among the standard protocols routinely used for toxicity tests of the reproductive system. Short-term tests are important to identify target sites and affected cell types, while longterm tests provide information on toxic effects of longterm dosing, covering one or more spermatogenic cycles (Zenick et al. 1994). Considering the popular use of $C$. ferrea, the seminal vesicle being a possible target organ, and the presence of substances with antifertility activity among its constituents, this study was designed to investigate the potential reproductive toxicity in male Wistar rats submitted to long-term treatments with an aqueous extract of this plant.

\section{MATERIALS AND METHODS}

\section{ANimals AND Housing}

Immature male Wistar rats (Rattus norvegicus Berkenhout 1769) (30 days old and weighing about $70 \mathrm{~g}$ ) and adult male Wistar rats (90 days old and weighing about $250 \mathrm{~g}$ ) were obtained from the vivarium of the Federal University of Juiz de Fora (UFJF), where they were born and bred. The animals were housed individually under standard laboratory conditions, with a $12 \mathrm{~h}$ light/12h dark photoperiod. They were fed on rat chow pellets and received water ad libitum. The experimental protocol was approved by the Ethical Committee of the Reproduction Biology Center (UFJF) (protocol number 013/ 2004-CEA), which follows the international principles in ethics for animal experimentation.

\section{PLANT MATERiAL}

C. ferrea Mart (Leguminosa) was collected in the Belém region (Pará State, Brazil) in 2005 and authenticated by Dr. Antonio Barioni Guzman in the Herbarium of the Biology Department of USP in Ribeirão Preto (São Paulo State, Brazil), where a voucher specimen registered under the number 3221 is kept. The air-dried fruits were cut into small pieces and macerated in distilled water to obtain a crude aqueous extract $(\mathrm{w} / \mathrm{w}$ yield $=23 \%)$. Afterwards, $100 \mathrm{~mL}$ of the crude extract was diluted to $300 \mathrm{~mL}$ of an aqueous solution to yield $76.6 \mathrm{mg} / \mathrm{mL}$ as the final concentration. The extract was, then, frozen for storage. The aqueous extract was subsequently reconstituted in water at the appropriate concentration for the experiment.

\section{Treatment Procedure}

Reproductive toxicity was assessed through two chronic test protocols. In the first protocol, 24 adult Wistar rats were selected at random and divided evenly into a treatment group (T1) and a control group (C1). In the second protocol, 30 immature Wistar rats were divided evenly into a treatment group (T2) and a control group (C2). The rats in the treatment groups received a single daily dose by gavage of $1 \mathrm{~mL}$ of $C$. ferrea extract of $300 \mathrm{mg} /$ $\mathrm{kg}$ of body weight, which was administered for 52 days (T1 group) or 104 days (T2 group). The 52 day period corresponds to the spermatogenic cycle of this species (Hilscher 1964). The control groups received $1 \mathrm{~mL}$ of distilled water following the same protocol as the treatment group.

During the experiments, the animals were observed twice daily for clinical signs of toxicity, such as piloerection, changes in locomotor activity and mortality (Manson and Kang 1994). Body weight was recorded before the beginning of treatment, at weekly intervals and at the end of treatment. Food consumption was monitored daily. 
The animals of the first protocol, $\mathrm{T} 1$ and $\mathrm{C} 1$, were euthanized by inhalation of an anesthetic (halothane) on the $53^{\text {rd }}$ day, and those of the second protocol, T2 and $\mathrm{C} 2$, on the $105^{\text {th }}$ day. Immediately after death, the following organs were dissected out and weighed: testes, left epididymis, seminal vesicle, prostate, liver, kidneys, lungs, brain and the pituitary gland. The left testis and epididymis were, then, fixed in Bouin for histological examination. To conduct a light microscope examination, the tissues were dehydrated in a graded series of ethanol, embedded in paraffin and sectioned at $3 \mu \mathrm{m}$ thickness for routine haematoxylin and eosin staining (Humason 1972).

Sperm was collected from the epididymal secretion of the right epididymis cauda. The secretion was placed in a $0.3 \mathrm{~mL}$ drop of physiological serum extract and later diluted in distilled water. From this homogenate, a sample was taken and a sperm count was obtained using a hemocytometer with improved double Neubauer ruling (Moraes 1994).

The Student's $t$ test and the Mann-Whitney test were applied for statistical comparison of the differences in data between the test groups $(\alpha=0.05)$ (Sokal and Rohlf 1996) and the results were expressed by mean and standard deviation (SD).

\section{RESULTS}

During the treatment period, no deaths and no changes in locomotor activity, piloerection, nor any other clinical signs of toxicity were observed. Body weight did not change significantly, and the treatment did not interfere with food consumption, although the average food intake of the treatment group (T2, 104-day test protocol) was systematically a little below the average consumption of the respective control group.

The weight of the reproductive organs, the accessory sex glands, the pituitary gland and other analyzed organs were not significantly different between control and treated groups on both toxicity test protocols (Tables I and II).

Sperm concentrations from the secretion of the right epididymis cauda were: control $(\mathrm{C} 1)=108.4 \pm$ $64 \times 10^{6} \mathrm{sperm} / \mathrm{mL}($ mean $\pm \mathrm{SD})$ and treated $(\mathrm{T} 1)=$ $191.4 \pm 138.3 \times 10^{6} \mathrm{sperm} / \mathrm{mL}$; control $(\mathrm{C} 2)=1095 \pm$ $334.8 \times 10^{6} \mathrm{sperm} / \mathrm{mL}($ mean $\pm \mathrm{SD})$ and treated $(\mathrm{T} 2)$
TABLE I

Organ weights of control and $C$. ferrea extract-treated Wistar rats submitted to chronic treatment, with an exposure of 52 days and death on the $53^{\text {rd }}$ day.

\begin{tabular}{l|c|c}
\hline \multirow{2}{*}{ Organ } & \multicolumn{2}{|c}{ Weight $(\mathrm{g})$} \\
\cline { 2 - 3 } & Control & Treated \\
\hline Brain & $1.15 \pm 0.08$ & $1.16 \pm 0.06$ \\
Pituitary $(\mathrm{mg})$ & $11.33 \pm 3.74$ & $13.0 \pm 3.64$ \\
Liver & $12.01 \pm 1.60$ & $12.62 \pm 1.90$ \\
Lung & $1.51 \pm 0.16$ & $1.53 \pm 0.12$ \\
Right kidney & $1.19 \pm 0.13$ & $1.23 \pm 0.11$ \\
Left kidney & $1.16 \pm 0.13$ & $1.20 \pm 0.11$ \\
Right testicle & $1.36 \pm 0.07$ & $1.41 \pm 0.03$ \\
Left testicle & $1.37 \pm 0.07$ & $1.41 \pm 0.07$ \\
Left epididymis & $0.42 \pm 0.04$ & $0.45 \pm 0.04$ \\
Seminal vesicle & $0.37 \pm 0.04$ & $0.40 \pm 0.11$ \\
Prostate & $0.30 \pm 0.05$ & $0.30 \pm 0.04$ \\
\hline
\end{tabular}

Results expressed in mean $\pm \mathrm{SD} . \mathrm{N}=12$.

TABLE II

Organ weights of control and $C$. ferrea extract-treated Wistar rats submitted to chronic treatment, with an exposure of 104 days and death on the $105^{\text {th }}$ day.

\begin{tabular}{l|c|c}
\hline \multirow{2}{*}{ Organ } & \multicolumn{2}{|c}{ Weight $(\mathrm{g})$} \\
\cline { 2 - 3 } & Control & Treated \\
\hline Brain & $1.31 \pm 0.06$ & $1.28 \pm 0.07$ \\
Pituitary $(\mathrm{mg})$ & $12.80 \pm 2.34$ & $12.87 \pm 1.64$ \\
Liver & $14.26 \pm 1.10$ & $14.12 \pm 1.67$ \\
Lung & $1.52 \pm 0.18$ & $1.44 \pm 0.15$ \\
Right kidney & $1.21 \pm 0.08$ & $1.18 \pm 0.12$ \\
Left kidney & $1.21 \pm 0.09$ & $1.16 \pm 0.11$ \\
Right testicle & $1.39 \pm 0.08$ & $1.36 \pm 0.08$ \\
Left testicle & $1.37 \pm 0.09$ & $1.34 \pm 0.08$ \\
Left epididymis & $0.51 \pm 0.03$ & $0.50 \pm 0.04$ \\
Seminal vesicle & $0.37 \pm 0.08$ & $0.37 \pm 0.08$ \\
Prostate & $0.26 \pm 0.06$ & $0.24 \pm 0.04$ \\
\hline
\end{tabular}

Results expressed in mean \pm SD. $\mathrm{N}=15$.

$=1079 \pm 196.6 \times 10^{6} \mathrm{sperm} / \mathrm{mL}$. There were no significant differences between the mean values of $\mathrm{C} 1$ and $\mathrm{T} 1$, and those of $\mathrm{C} 2$ and T2. Figures 1 and 2 show the proportion of normal and abnormal spermatozoa of control and treated groups; again, there were no statistical differences between them. The most common abnormalities were headless, tailless and curly tailed spermatozoa; their concentrations in the 52- and 104-day test protocol were also similar. 


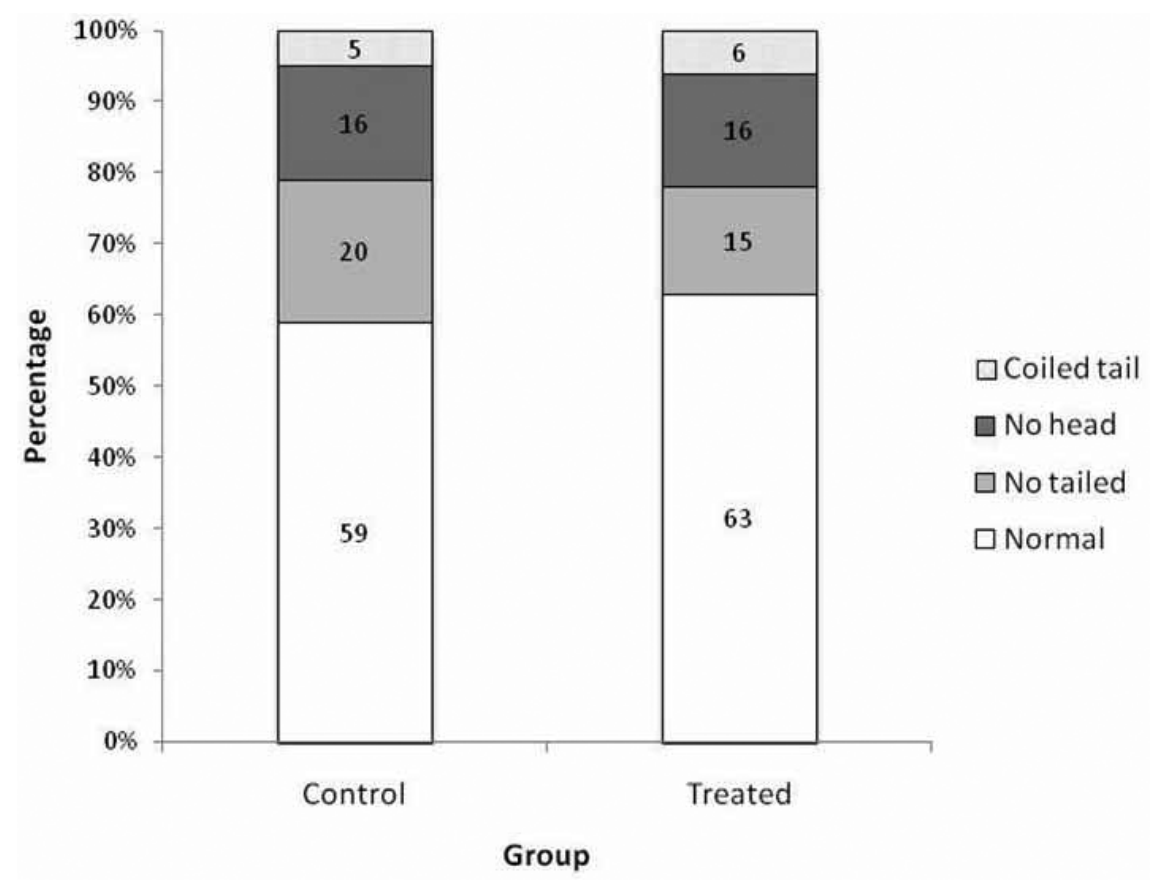

Fig. 1 - Proportion of normal and abnormal spermatozoa of control and C. ferrea extract-treated Wistar rats submitted to chronic treatment, with an exposure of 52 days and death on the $53^{\text {rd }}$ day. $\mathrm{N}=12$.

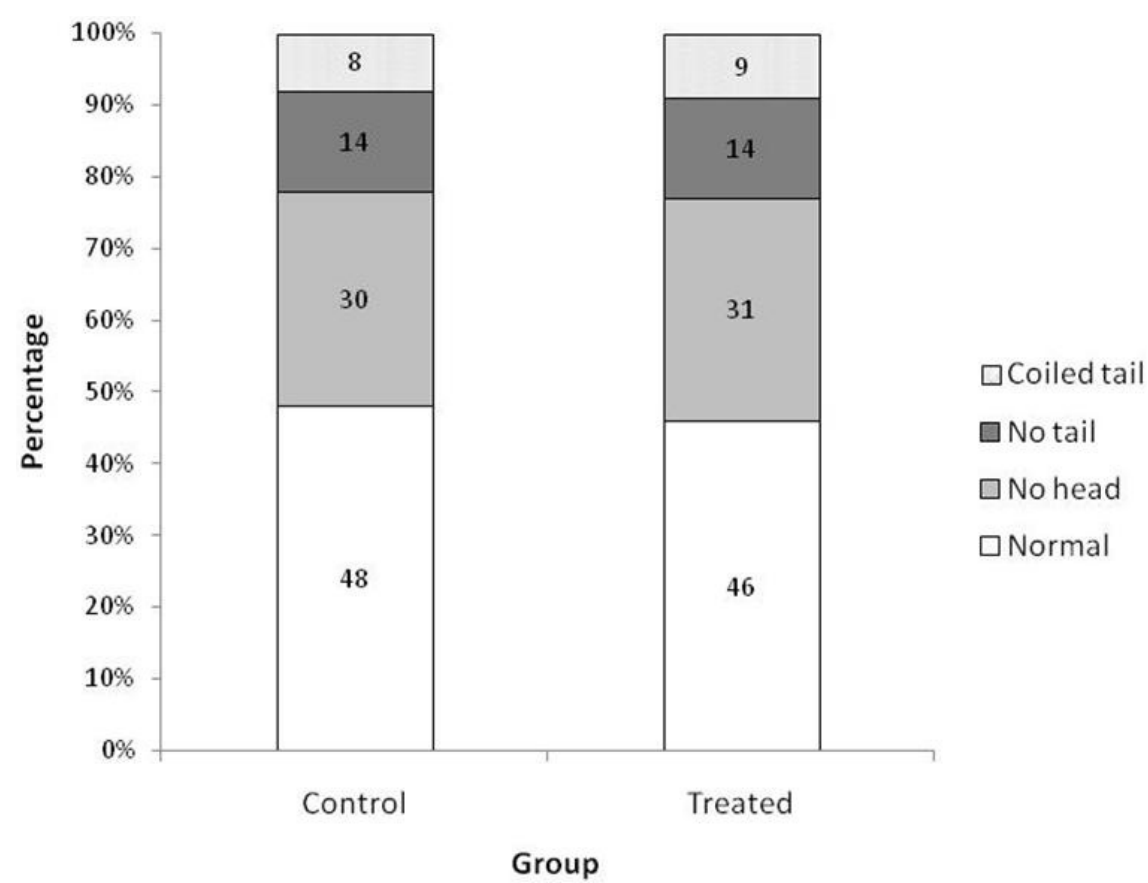

Fig. 2 - Proportion of normal and abnormal spermatozoa of control and C. ferrea extract-treated Wistar rats submitted to chronic treatment, with an exposure of 104 days and death on the $105^{\text {th }}$ day. $\mathrm{N}=15$. 
The histological examination revealed that there was no structural change in the seminiferous epithelium of the treated groups' testis when compared to that of the control groups. Similarly, the epididymis of control and treated rats showed a normal epithelium lining and the presence of spermatozoa in all segments (head, body and tail) of this organ.

\section{DISCUSSION}

Plants contain many active compounds that are probably responsible for their different therapeutic properties exploited by folk medicine. However, these natural occurring compounds may also exert a toxic effect in the development or normal functioning of the reproductive system (Abdel-Magied et al. 2001, Bidwai et al. 1990, Hiremath et al. 1997, Montanari et al. 1998, Rajasekaran et al. 1988). Coumarin, flavonoids and sitosterol are plant substances that have been related to the occurrence of adverse effects on the reproductive system. Previous studies have shown that coumarin had antifertility activity in female rats (Ulubelen et al. 1994), whereas flavonoids produced antiandrogenic activities in male dogs (Bhargava 1989) and sitosterol reduced sperm production in rats (Malini and Vanithakumari 1991). These substances have been reported to be among the active compounds of the aerial parts of $C$. ferrea, thus suggesting a possible toxic behavior of this plant on the reproductive system.

Reproductive tests designed to evaluate the toxicity of compounds are important to identify which targets in the reproductive system are affected by the toxin. Toxic agents may reduce male fertility potential by impairing sperm production, maturation, function and survival by acting directly on the sperm in the testis milieu or by affecting epididymal function. In the accessory sex gland secretions, the toxic agents could affect sperm directly or affect the female genital tract. The chronic reproductive test protocols include organ weight data, measures of sperm production and quality, and histopathologic evaluations as some of their major end points. They are also recommended to assess male reproductive toxicity because the exposure period covers the entire spermatogenic cycle (Zenick et al. 1994).

C. ferrea is a plant used by the population for its therapeutic properties, although very little is known about its side effects due to the lack of pre-clinic and clinic studies. A preliminary assessment of the toxicity of this plant showed a non significant weight reduction of the seminal vesicle of rats submitted to short-term tests using an aqueous extract of $C$. ferrea (Reboredo et al. 2006). Following the acute reproductive screening, the next step involves the investigation of the long-term exposure of the substance on the organism. Therefore, in this work, two long-term treatment protocols were performed on an animal experimental model to investigate a possible toxic effect on several organs, with emphasis on the reproductive system.

Since the aqueous extract of $C$. ferrea has been used in an acute toxicity assessment on the reproductive system of Wistar rats at the dose of $300 \mathrm{mg} / \mathrm{kg}$ of body weight (Reboredo et al. 2006), the same dose was selected in this experiment. This dose level also corresponds to the dose used on previous studies for the evaluation of the analgesic and anti-inflammatory properties of this plant (Carvalho et al. 1996). The choice of one dose is also in accordance with the guidelines of the Ethical Committee to reduce the number of animals in the experimental procedure. The long-term administration of the extract did not seem to have caused any toxic effect in the rats from both test protocols, since no deaths nor clinical signs of toxicity, such as locomotor activity changes and piloerection, were detected.

Body weight reduction of animals under treatment is indicative of toxic action of a substance in the organism (Hiremath et al. 1997). In the present work, the treatments did not cause a significant body weight reduction nor did interfere with food consumption in the treated animals, which presented similar weight gain when compared to the control.

A weight loss of the reproductive organs is under hormonal control and could suggest a disturbance of the reproductive endocrine functions (Elbetieha et al. 2001). In the testis, the production of sex steroid hormones and male gametes is regulated by the folliclestimulating hormone (FSH) and luteinizing hormone (LH), which are secreted by the pituitary gland. An impairment of the normal functioning of this gland could, then, interfere with the development and functioning of the male reproductive system (Mahony and Hodgen 1995). In this study, the treatments did not produce 
undesirable side effects on the pituitary glands, nor did affect the organs of the reproductive system or the accessory sex glands, as evidenced by their weights that were not changed significantly. At the beginning of the 104-day treatment group, the reproductive organs of the rats were not completely developed, but by the time the treatment was over, the animals were fully grown and sexually mature. Although some sort of damage would be expected to occur because the animals were still undergoing sexual maturation during the experimental procedure, no androgenic or anti-androgenic effects were detected in the treated animals, giving further support to the normal functioning of the reproductive organs, including the androgen-dependent accessory sex glands. Apart from the reproductive organs, the treatment did not affect the other vital organs such as the liver, whose hepatotoxic effect has been reported in the literature (Di Stasi et al. 2002).

In addition to the organ weight data, a comprehensive assessment of the effects of chemicals on male reproductive functioning also requires the study of effects on spermatogenesis and the quality of the spermatozoa (Blazak et al. 1985, Wu et al. 2010). Despite the long duration of the treatments and the presence of active compounds with reported toxic action on the reproductive system, the $C$. ferrea extract was not toxic to the testis, the left epididymis, the ventral prostate and the seminal vesicle. No impairment of the spermatogenic cycle was observed, and the sperm concentration from the secretion of the right epididymis cauda did not differ significantly between the control and treated groups of both test protocols. The sperm morphology seemed unaffected by the treatment as the proportion of normal and abnormal spermatozoa was comparatively similar between the control and treated groups. These observations were corroborated by the histological data that showed no alteration on the histoarchitecture of the testis and epididymis.

In conclusion, the data in this work points to the absence of toxicity of the aqueous extract of C. ferrea considering that no toxic effect was observed in the Wistar rat following a long duration exposure. The androgen production and gamete secretion were not affected, showing a normal functioning of the reproductive system and its related endocrine system.

\section{ACKNOWLEDGMENTS}

The authors are grateful to Prof. José Carlos Tavares for supplying the botanical material, to Prof. Henrique Hippert for helping with the statistical analysis, and to Dr. Michael Paluch for reviewing the English version of this manuscript. This work was sponsored by Fundação de Amparo à Pesquisa do Estado de Minas Gerais (FAPEMIG).

\section{RESUMO}

Caesalpinia ferrea Mart (Leguminosae) é uma planta medicinal utilizada principalmente no tratamento do diabetes, dentre outras propriedades terapêuticas, mas que também apresenta relatos de hepatotóxicos. Embora apresente em sua constituição substâncias capazes de interferirem na fertilidade, como flavonóides e cumarina, nenhum estudo foi ainda realizado para avaliar os efeitos adversos dessa planta no funcionamento do sistema reprodutor após tratamento de longa duração. Portanto, este trabalho foi desenvolvido com o objetivo de avaliar a utilização segura e os efeitos de C. ferrea nos órgãos vitais, no sistema reprodutor e na produção de espermatozóides de ratos Wistar submetidos a tratamento crônico. Animais imaturos e adultos foram tratados com o extrato aquoso de C. ferrea na dose de $300 \mathrm{mg} / \mathrm{kg}$ de peso corporal, administrado durante um ou dois ciclos espermatogênicos dessa espécie. Os órgãos reprodutores e vitais foram analisados e os espermatozóides foram coletados na secreção epididimária proveniente da cauda do epidídimo direito. A administração crônica de $C$. ferrea não alterou significativamente o peso corporal e nem o peso dos órgãos reprodutores e vitais. A produção de gametas também não foi afetada. Os dados sugerem que a utilização crônica de $C$. ferrea não interfere com o funcionamento normal do sistema reprodutor do rato Wistar.

Palavras-chave: Caesalpinia ferrea, rato Wistar, sistema reprodutor, avaliação toxicológica, tratamento crônico e subcrônico.

\section{REFERENCES}

AbDel-Magied EM, ABdel-Rahman HA ANd HarraZ FM. 2001. The effect of aqueous extract of Cynomorium coccineum and Withania somnifera on testicular development in immature Wistar rats. J Ethnopharmacol 75: $1-4$.

BACHI EM, Sertie JAA, Villa N ANd KATZ H. 1995. Antiulcer action and toxicity of Styrax camporum and Caesalpinia ferrea. Planta Med 61: 204-207. 
BHARGAVA SK. 1989. Antiandrogenic effects of a flavonoid rich fraction of Vitex negundo seeds: a histological and biochemical study in dogs. J Ethnopharmacol 27: 327339.

BidWAi PP, Wangoo D ANd Bhullar N. 1990. Antispermatogenic action of Celastrus paniculatus seed extract in the rat with reversible changes in the liver. J Ethnopharmacol 28: 293-303.

BLazak WF, ERnst TL and Stewart BE. 1985. Potential indicators of reproductive toxicity: testicular sperm production and epididymal sperm number, transit time, and motility in Fischer 344 rats. Fund Appl Toxicol 5: 1097-1103.

Born SL, Caudill D, Smith BJ And Lehman-MCKEEMAN LD. 2000. In vitro kinetics of coumarin 3,4epoxidation: application to species differences in toxicity and carcinogenicity. Toxicol Scienc 58: 23-31.

BragançA LAR. 1996. Plantas Medicinais Antidiabéticas. Niterói, RJ, Brasil, EDUFF Press, p. 172.

Carvalho JCT, TeIXeIra JRM, Souza PJC, Bastos JK, Filho DS AND SARTi SJ. 1996. Preliminary studies of analgesic and anti-inflammatory properties of Caesalpinia ferrea crude extract. J Ethnopharmacol 53: 175-178.

Di Stasi LC, Guimarães EM, Santos CM, HirumaLimA CA AND SOUZA-BRITO ARM. 2002. Fabales medicinais. In: DI STASI LC AND HiRUMA-LimA CA (Eds), Plantas medicinais na Amazônia e na Mata Atlântica, São Paulo, SP, Brasil, Editora UNESP, p. 276-320.

Dixit VP, GUPTA RS AND GUPTA S. 1989. Antifertility plant products: testicular cell population dynamics following solasodine $\left(\mathrm{C}_{27} \mathrm{H}_{43} \mathrm{O}_{2} \mathrm{~N}\right)$ administration in Rhesus monkey (Macaca mulatta). Androl 21: 542-546.

Elbetieha A, Bataineh H, Darmani H And Al-HaMOOD MH. 2001. Effects of long-term exposure to manganese chloride on fertility of male and female mice. Toxicol Lett 119: 193-201.

GonzALEZ FG, BArros SBM And BACHI EM. 2004. Atividade antioxidante e perfil fitoquímico de Caesalpinia ferrea Mart. Braz J Pharmacol Scienc 40 (supl 1), 79.

He Y, Zeng F, Liu Q, Ju W, Fu H, Hao H, Li L And Xie Y. 2010. Protective effect of magnesium isoglycyrrhizinate on ethanol-induced testicular injuries in mice. J Biomed Res 24(2): 153-160.

Hilscher W. 1964. Beitrage zur orthologre und palhologie des "spermatogoniogenes" der ratte. Beitr Pathol Anat 130: 69-132.
Hiremath SP, BADAmi S, SWAMY HKS, PATIL SB AND LONDONKAR RL. 1997. Antiandrogenic effect of Striga orobanchioides. J Ethnopharmacol 56: 55-60.

Humason GL. 1972. Animal Tissue Techniques. San Francisco: WH Freeman, p. 641.

KimmeL GL, Clegg E AND CRISP TM. 1995. Reproductive toxicity testing: A risk assessment perspective. In: Witorsch RJ (Ed), Reproductive Toxicology, New York, Raven Press, p. 75-98.

Kritchevsky D And Chen SC. 2005. Phytosterols health benefits and potential concerns: a review. Nut Res 25: 413-428.

Maclatchy DL and Van Der KraAK GJ. 1995. The phytoestrogen $\beta$-sitosterol alters the reproductive endocrine status of gold fish. Toxicol Appl Pharmacol 134: 305-312.

Mahony MC And Hodgen GD. 1995. Toxic effects on the hypothalamus-anterior pituitary-gonadal axis, control on the male and female reproductive system, and related issues. In: Witorsch RJ (Ed), Reproductive Toxicology, New York, Raven Press, p. 195-213.

Malini T And VAnithakumari G. 1991. Antifertility effects of $\beta$-sitosterol in male albino rats. J Ethnopharmacol 35: 149-153.

MAnson JM AND KANG YJ. 1994. Test methods for assessing female reproductive and developmental toxicology. In: HAYE AW (Ed), Principle and methods of toxicology, $3^{\text {rd }}$ ed., Raven Press, New York, p. 980-1037.

Montanari T, Carvalho JE ANd Dolder H. 1998. Antiespermatogenic effect of Achillea millefolium L. in mice. Contraception 58: 309-313.

Moraes GES. 1994. Espermocitograma. Porto Alegre, RS, Brasil, Editora Médica Missau, p. 61-93.

NAKamura ES, Kurosaki F, ARisaWa M, MukainaKa T, TAKayasu J, OKUda M, TOKUdA H, Nishino H AND PASTORE F. 2002. Cancer chemopreventive effects of a Brazilian folk medicine, Juca, on in vivo two-stage skin carcinogenesis. J Ethnopharmacol 81: 135-137.

RAJASEKARAN M, BAPNA JS, LAKSHMANAN S, RAMAChandran Nair aG, Veliath AJ And PanchanaDAM M. 1988. Antifertility effect in male rats of oleanolic acid, a triterpene from Eugenia jambolana flowers. J Ethnopharmacol 24: 115-121.

Reboredo MM, Lucinda LMF, Rocha CB, QueIRoZ GT, Faria VC, Vieira VA, Carvalho JCT and SÁ RCS. 2006. Avaliação da toxicidade do extrato aquoso de Caesalpinia ferrea em órgãos vitais, no sistema repro- 
dutor e na produção de espermatozóides de ratos Wistar submetidos a tratamento subagudo. Bol Cent Biol Reprod UFJF 25: 17-29.

SOKAL RR AND RoHLF FJF. 1996. Biometry. The principles and practice of statistics in biological research. New York, WH Freeman and Co., p. 850.

Ulubelen A, Ertugrul L, Birman H, Yigit R, ERSEVEN G AND OlgaC V. 1994. Antifertility effects of some coumarins isolated from Ruta chalepensis and $R$. chalepensis var. latifolia in rodents. Phytother Res 8: 233-236.

Wang H, Huang P, Lie T, Li J, Hutzc RJ, Li K And SHI F. 2010. Reproductive toxicity of acrylamide-treated male rats. Rep Toxicol 29: 225-230.
Wu P-F, Chiang T-A, Chen M-T, LeE C-P, Chen P-H, Ko AM, YAng K-J, Chang P-Y, Ke D-S And Ko YC. 2010. A characterization of the antioxidant enzyme activity and reproductive toxicity in male rats following sub-chronic exposure to areca nut extracts. J Haz Mat 178: $541-546$.

Zenick H, Clegg ED, Perreault SD, Klinefelter GR AND GRAY LE. 1994. Assessment of male reproductive toxicity: a risk assessment approach. In: HAYES AW (Ed), Principles and Methods of Toxicology, New York, Raven Press, p. 937-988. 